\title{
On the nature of the university and what it means for nursing education - La nature de l'université et ses implications pour la formation en sciences infirmières
}

\author{
Jacinthe I. Pepin \\ Université de Montréal, jacinthe.pepin@umontreal.ca \\ Florence Myrick \\ amyrick@ualberta.ca
}

Follow this and additional works at: https://qane-afı.casn.ca/journal

Part of the Nursing Administration Commons, and the Scholarship of Teaching and Learning Commons

\section{Recommended Citation}

Pepin, Jacinthe I. and Myrick, Florence (2018) "On the nature of the university and what it means for nursing education - La nature de l'université et ses implications pour la formation en sciences infirmières," Quality Advancement in Nursing Education - Avancées en formation infirmière: Vol. 4: Iss. 2, Article 1.

DOI: https://doi.org/10.17483/2368-6669.1189

This Editorial is brought to you for free and open access by Quality Advancement in Nursing Education - Avancées en formation infirmière. It has been accepted for inclusion in Quality Advancement in Nursing Education - Avancées en formation infirmière by an authorized editor of Quality Advancement in Nursing Education - Avancées en formation infirmière. 


\section{On the nature of the university and what it means for nursing education}

In her intellectual history of the Laurendeau-Dunton Commission on bilinguism and biculturalism in Canada, held throughout the 1960s, Lapointe-Gagnon (2018) reports on the general understanding of the nature of the university at the time. Citing Gérard Pelletier, the author underlines the evolving view of universities: from places to meet, universities became in the 1960s societies of students and professors engaged in a common good. Most engaged Commissioners held a faculty position at some point in their working lives. What would you say the nature of the university is today and what does it mean for nursing education?

There are many contemporary answers to this question. Among them, the Global Commission on the Education of Health Professionals describes universities as open and interdependent systems organized in communities of learning that "generate knowledge-related global public goods" (Frenk et al. 2010, p.1954). Moreover, Sullivan and Rosen (2008) view the role of higher education as shaping a life of the mind for practice, warning against the danger of preparing for "technical professionalism", and linking the practical and the intellectual dimensions of life. In fact, these scholars suggest that the focus of education in the various disciplines should be on the social responsibility and ethical commitment to the broader good, in this case equity in health.

Nursing education then would be concerned with preparing nurses for their social responsibility and ethical commitment to equity in health, with a mind for practice and for transforming healthcare services in complex and diverse environments. (Frenk et al., 2010; Sullivan \& Rosen, 2018). Research on nursing education would have to expand and to deepen, for example through solid evaluation of innovations and through research programs, to steadily generate the knowledge required for the global change. How are we organising in learning communities with students and professors, patients and clinicians, public representatives and policy makers, locally and globally?

Articles in this issue of the QANE/ AFI, as well as the interview with the 2017 Pat Griffin scholar, are of particular interest in this regard, as they remind us of the diversity of students, of internationally educated nurses, and of the health care concerns of communities and populations. Research that honor the Truth and Reconciliation Calls to Action (Martin et al.; Rohatinsky et al.), or that strive to understand transformation in becoming a registered nurse (Nordstrom et al.) represent such examples towards preparing nurses for social responsibility and ethical commitment in open and interdependent systems. Knowledge on strategies such as cognitive companionship (Deschênes et al.), clinical teaching (Jennings \& Brett), and case studies in flipped classrooms (Mackie) are examples towards linking the practical and the intellectual dimensions of professional education in interdependent systems.

More thinking though needs to be done on the interdependence in nursing education for today and tomorrow's practice as 'Nursing education is preparation for remarkably hard work. This complexity and richness characteristic of the nursing profession is paralleled by the complexity of its contexts of practice" (Shulman in Benner et al., 2010, p. XI). 
As we extend our sincere gratitude to our numerous committed reviewers, we wish you a fruitful reading,

\section{La nature de l'université et ses implications pour la formation en sciences infirmières}

Dans son ouvrage concernant l'histoire intellectuelle de la Commission LaurendeauDunton sur le bilinguisme et le biculturalisme au Canada, qui s'est tenue tout au long des années 1960, Valérie Lapointe-Gagnon (2018) fait état de la compréhension générale de la nature de l'université à l'époque. Citant Gérard Pelletier, l'auteure expose le changement de perception des universités : de lieux de rencontre, elles sont devenues dans les années 1960 des sociétés d'étudiants et de professeurs engagés dans la poursuite d'un bien commun. En effet, la plupart des commissaires impliqués avaient déjà occupé un poste de professeur dans leur carrière. Selon vous, quelle est la nature de l'université de nos jours, et qu'est-ce que cela implique pour la formation en sciences infirmières?

Il y a aujourd'hui plusieurs réponses à cette question. À ce propos, la Global Commission on the Education of Health Professionals [commission mondiale sur la formation des professionnels en santé] décrit les universités comme des systèmes ouverts et interdépendants organisés en communautés d'apprentissage qui «[traduction] génèrent des biens collectifs mondiaux axés sur les connaissances » (Frenk et al., 2010, p. 1954). En outre, Sullivan et Rosen (2008) considèrent que le rôle de l'éducation supérieure est de façonner une vie de l'esprit au service de la pratique. Mettant en garde contre les dangers d'une préparation à un certain «professionnalisme technique », ils proposent que cette formation doive marier les aspects pratiques et intellectuels de la vie. En fait, ces experts proposent que la formation dans plusieurs disciplines doive se centrer sur la responsabilité sociale et l'engagement éthique envers le bien commun, c'est-à-dire l'équité en matière de santé dans le cas présent.

La formation en sciences infirmières viserait alors à préparer les infirmières pour leur responsabilité sociale et leur engagement éthique envers l'équité en matière de santé, et ce, en ayant développé une pensée pour façonner la pratique et pour transformer les services de santé dans des milieux complexes et diversifiés (Frenk et al., 2010; Sullivan et Rosen, 2018). La recherche en formation infirmière devrait alors gagner en étendue et en profondeur, possiblement par le biais d'évaluations rigoureuses des innovations ainsi que par l'établissement de programmes de recherche visant à générer de manière assidue les connaissances nécessaires à un changement mondial. À l'échelle locale et internationale, comment organisons-nous nos communautés d'apprentissage avec les étudiants et les professeurs, les patients et les cliniciens, les représentants du public et les décideurs?

À ce sujet, des articles du présent numéro de la revue QANE-AFI et l'entrevue réalisée avec la lauréate de 2017 de la bourse Pat Griffin sont particulièrement intéressants, car ils nous rappellent la diversité des étudiants, des infirmières formées à l'étranger et des préoccupations des soins de santé des communautés et populations. Les recherches qui honorent les appels à l'action de la Commission de vérité et réconciliation (Martin et al.; Rohatinsky et al.) ou qui s'efforcent de comprendre la transformation nécessaire pour devenir infirmière (Nordstrom et al.), sont des exemples de préparation des infirmières pour la responsabilité sociale et 
l'engagement éthique dans des systèmes ouverts et interdépendants. Les connaissances développées sur des stratégies telles que,] le compagnonnage cognitif (Deschênes et al.), l'enseignement en milieu clinique (Jennings \& Brett) et les études de cas dans une classe inversée (Mackie) sont des exemples joignant les aspects pratiques et intellectuels de la formation pour une profession au sein de systèmes interdépendants.

Il reste toutefois nécessaire d'approfondir la réflexion sur l'interdépendance dans la formation en sciences infirmières pour préparer à la pratique actuelle et future, car : «[traduction] La formation infirmière prépare à un travail remarquablement difficile. Le caractère complexe et riche de la profession infirmière va de pair avec la complexité de ses contextes de pratique » (Shulman dans Benner et al., 2010, p. XI).

En exprimant nos remerciements sincères à nos nombreuses évaluatrices engagées, nous vous souhaitons une lecture enrichissante.

Jacinthe Pepin RN PhD, Co-Editor-in-Chief - Corédactrice en chef

Florence Myrick RN PhD, Co-Editor-in-Chief - Corédactrice en chef

\section{References / Références}

Benner, P., Sutphen, M., Leonard, V., \& Day, L. (2010). Educating nurses: A call for radical transformation. San Francisco, CA: Jossey-Bass.

Frenk, J., Chen, L., Bhutta, Z. A., Cohen, J., Crisp, N., Evans, T., ... Zurayk, H. (2010). Health professionals for a new century: Transforming education to strengthen health systems in an interdependent world. The Lancet, 376(9756), 1923-1958. doi: 10.1016/S0140-6736(10)61854-5

Lapointe-Gagnon, V. (2018). Panser le Canada. Une histoire intellectuelle de la commission Laurendeau-Dunton. Bibliothèques et Archives nationales du Québec et du Canada : Les éditions du Boréal.

Sullivan, W.M. and Rosen, M.S. (2008). A New Agenda for Higher Education. Shaping a Life of the Mind for Practice. Stanford, CA: The Carnegie Foundation for the Advancement for Teaching. 